\title{
EKSPERIMENTASI MODEL PEMBELAJARAN KOOPERATIF TIPE JIGSAW DAN JIGSAW BERBANTU MEDIA FLASH PADAMATERI DIMENSI TIGA DITINJAU DARI GAYA BELAJAR SISWA KELAS XI SMK DI KABUPATEN SRAGEN TAHUN AJARAN 2015/2016
}

\author{
Rina Kurniawati ${ }^{1}$, Riyadi $^{2}$, dan Imam Sujadi ${ }^{3}$ \\ ${ }^{1,2,3,}$ Prodi Magister Pendidikan Matematika, FKIP Universitas Sebelas Maret Surakarta
}

\begin{abstract}
This research was purposed to determine: (1) which one produced better mathematics learning achievement, cooperative learning model type Jigsawand Jigsaw Flash, or direct instruction; (2) which one had better mathematics learning achievement between students with visual learning style, those with auditory or those with kinesthetic learning style; (3) on each learning style, which one learning model that produced better mathematics learning achievement, cooperative learning model type Jigsawand Jigsaw Flash or direct instruction (4) on each learning model, which one student had better mathematics learning achievement, student who had visual learning style, those with auditory or those with kinesthetic learning style. This study was a quasi-experimental study with factorial $3 \times 3$ design. Population in this research were eleventh grade students of Vocational High School in Sragen. Sample collection were done by stratified cluster random sampling. Data collection were done by the method of documentation in order to test the balance of the population, the questionnaire were used to determine the students learning style and test were used to know the students achievement on material dimension three. Data analysis techniques used ANAVA two ways with unbalanced cells. The results of this study concluded as follows (1) cooperative learning model type Jigsaw Flash gave better mathematics learning achievement than cooperative learning type Jigsaw and direct instruction, cooperative learning type Jigsaw gave better mathematics learning achievement than direct instruction; (2) Students with kinesthetic learning style had better mathematics learning achievement than students with visual learning style and auditory learning style; students with visual learning style had better mathematics learning achievement than students with auditory learning style; (3) on each learning style, cooperative learning model type Jigsaw Flash gave better mathematics learning achievement than cooperative learning type Jigsaw and direct instruction, cooperative learning type Jigsaw gave better mathematics learning achievement than direct instruction; (4) on each learning model (Jigsaw, Jigsaw Flash, and direct instruction), students with kinesthetic learning style had better mathematics learning achievement than students with visual learning style and auditory learning style with visual learning style had better mathematics learning achievement than students with auditory learning style.

Keywords: Learning Model, Jigsaw, Jigsaw Flash, Learning Style, learning achievement
\end{abstract}

\section{PENDAHULUAN}

Peningkatan kualitas sumber daya manusia merupakan salah satu penekanan daritujuan pendidikan, seperti yang tertuang dalam Undang-Undang Nomor 20 tahun 2003tentang Sistem Pendidikan Nasional Bab II pasal 3 yang berbunyi: "Pendidikan nasional bertujuan mengembangkan kemampuan dan membentuk watak serta peradaban bangsa yang bermartabat dalam rangka mencerdaskan bangsa, bertujuan untuk berkembangnya potensi siswa agar menjadi manusia yang beriman dan bertakwa kepada 
Tuhan Yang Maha Esa, berakhlak mulia, sehat, berilmu, cakap, kreatif, mandiri dan menjadi warga negara yang demokratis serta bertanggung jawab."Selain itu, tujuan pendidikan nasional dalam menjamin mutu pendidikan dan mencerdaskan kehidupan bangsa serta membentuk watak dan peradaban yang bermartabat telah diupayakan pemerintah melalui perwujudan pendidikan yang bermutu pada setiap satuan pendidikan di Indonesia.

Berdasarkan laporan hasil Ujian Nasional (UN) dari Badan Standar Nasional Pendidikan (BSNP) 2014/2015 untuk Kabupaten Sragen rata-rata nilai ujian nasional mata pelajaran matematika sebesar 49,0, nilai ini masih berada di bawah rata-rata propinsi yaitu sebesar 57,7. Dari uraian di atas terlihat jelas bahwa nilai rata-rata matematika pada UN SMK tahun 2014/2015 di Kabupaten Sragen dari seluruh mapel UN rendah dan kurang memuaskan. Hal ini menunjukkan bahwa penguasaan dan daya serap siswa terhadap pembelajaran matematika masih rendah. Salah satu materi matematika dengan daya serap rendah adalah dimensi tiga.

Pada proses pembelajaran matematika, siswa mempelajari konsep-konsep yang saling berkaitan. Bila salah satu konsep tidak dipahami dengan baik, maka hal ini akan berpengaruh pada pemahaman konsep selanjutnya yang berkaitan. Kadang pembelajaran di sekolah juga kurang memperhatikan prakonsepsi yang dimiliki siswa.Padahal prakonsepsi yang dimiliki siswa berbeda-beda dan belum tentu benar.Kondisi demikian sangat memungkinkan rendahnya pemahaman konsep matematika pada diri siswa.Hal ini sesuai dengan hasil penelitian Howe dalam Wilantara (2003: 3), bahwa rendahnya pemahaman konsep matematika pada siswa dapat berakibat buruk.Kegiatan belajar mengajar yang tidak memperhatikan pentingnya pemahaman konsep siswa menyebabkan kesulitan belajar dan akhirnya berakibat pada rendahnya prestasi belajar siswa. Menurut Price (1999: 12) mengemukakan bahwa ada dua macam hasil atau prestasi belajar matematika yang harus dikuasai oleh siswa, pemahaman konsep (concept understanding) dan kemampuan atau keterampilan berhitung (computation skill). Berdasarkan hasil belajar semacam itu maka Price (1999: 16) mengemukakan bahwa kurikulum bidang studi matematika hendaknya mencakup tiga elemen, yaitu (1) konsep, (2) keterampilan komputasi, dan (3) pemecahan masalah.

Rendahnya kemampuan matematika terdiri dari pemahaman konsep dan keterampilan komputasi maupun daya serap khususnya pada materi geometri. Selain itu, ada banyak faktor yang mempengaruhi keberhasilan siswa dalam pembelajaran, baik faktor eksternal maupun faktor internal. Menurut Slameto (2003:54-72), faktor eksternal adalah faktor yang berasal dari luar siswa, antara lain: guru, sarana dan prasarana 
pembelajaran, ketepatan guru dalam memilih model pembelajaran, kebijakan pemerintah, lingkungan sosial siswa di sekolah maupun keluarga dan kurikulum sekolah, sedangkan faktor internal adalah faktor yang berasal dari dalam diri siswa, antara lain: sikap terhadap belajar, motivasi belajar, pengolahan bahan belajar, menyimpan perolehan hasil belajar, menggali hasil belajar yang tersimpan, kemampuan berprestasi atau unjuk belajar, rasa percaya diri siswa, intelegensi dan keberhasilan belajar, kebiasaan belajar, dan citacita dari siswa. Apabila faktor-faktor tersebut dapat diakomodasi dengan baik, maka kemungkinan siswa mengalami kesulitan belajar akan semakin kecil.

Salah satu faktor eksternal yang diduga mempengaruhi rendahnya prestasi belajar matematika yaitu belum semua guru mampu memilih dan menerapkan model pembelajaran yang tepat dan sesuai dengan tujuan pembelajaran untuk suatu kompetensi tertentu. Keberhasilan pendidikan di sekolah berkaitan erat dengan model pembelajaran yang dilakukan oleh guru di dalam kelas. Begitu pula pada pembelajaran matematika, model pembelajaran langsung yang sering digunakan oleh guru membuat siswa cenderung pasif karena semua kegiatan pembelajaran terfokus pada guru sebagai sumber utama pengetahuan. Siswa hanya mendengarkan penjelasan materi dari guru, kemudian guru memberi contoh, selanjutnya mengajukan pertanyaan kepada siswa. Jika tidak ada siswa yang bertanya, guru memberikan latihan soal dan pekerjaan rumah. Model pembelajaran seperti ini membuat siswa kurang berpartisipasi selama proses pembelajaran sehingga siswa merasa bosan dan materi yang disampaikan oleh guru tidak terserap dengan baik oleh siswa. Untuk itu diperlukan model pembelajaran yang dapat membuat pembelajaran menjadi menyenangkan sehingga siswa tidak merasa bosan dan materi yang disampaikan dapat diserap dengan baik oleh siswa.

Banyak penelitian yang menyebutkan bahwa model pembelajaran kooperatif dapat memberikan peningkatan yang signifikan terhadap hasil belajar siswa. Salah satunya adalah penelitian yang dilakukan oleh Parveen \& Batool (2012), dari penelitian tersebut diperoleh bahwa prestasi belajar siswa dengan pembelajaran kooperatif lebih baik dibandingkan prestasi belajar siswa dengan pembelajaran langsung. Model pembelajaran kooperatif adalah pembelajaran yang inovatif dan mampu membiasakan siswa berpikir logis, analitis, kritis dan kreatif serta menjadikan siswa dapat bertukar ide dengan siswa lain karena pembelajaran dilakukan secara berkelompok sedangkan guru berfungsi sebagai fasilitator. Johnson, Johnson \& Holubec dalam Attle \& Baker (2007) dalam penelitiannya juga menyatakan bahwa "Cooperative learning yields increased efforts among students, more positive interpersonal relationships, and improved mental health when compared to purely individualistic learning". Artinya hasil pembelajaran 
kooperatif meningkatkan upaya-upaya di kalangan siswa, hubungan interpersonal yang lebih positif, dan meningkatkan kesehatan mental bila dibandingkan dengan pembelajaran individual. Jadi, dengan pembelajaran kooperatif diharapkan siswa tidak lagi pasif dan hanya mendengarkan penjelasan guru melainkan aktif bekerja bersama dengan teman satu kelompok untuk menyelesaikan permasalahan yang diberikan oleh guru.

Bekerja di dalam kelompok ini juga memiliki kekurangan, salah satunya adalah memungkinkan siswa dengan kemampuan rendah hanya bergantung pada siswa dengan kemampuan tinggi. Untuk itu dalam penelitian ini peneliti memilih model pembelajaran kooperatif tipe Jigsaw dan Jigsaw berbantu media flash untuk meminimalisasi kemungkinan siswa hanya bergantung pada temannya yang berkemampuan tinggi, karena kedua model ini mengharuskan setiap siswa untuk memahami materi dan dapat menjelaskan hasil diskusi mereka. Slavin (2010) menyebutkan "In general, two elements must be present if co-operative learning is to be effective: group goals and individual accountability". Artinya, agar pembelajaran kooperatif menjadi efektif maka ada dua komponen yang harus ada, yaitu tujuan kelompok dan tanggung jawab individu. Dengan kata lain, agar keberhasilan pembelajaran kooperatif tercapai maka sebuah kelompok harus bekerja untuk beberapa tujuan dan untuk mencapai beberapa tujuan tersebut diperlukan tanggung jawab dari masing-masing individu.

Model pembelajaran kooperatif tipe Jigsaw merupakan salah satu model pembelajaran kooperatif yang mendorong siswa aktif dan saling membantu dalam menguasai materi pelajaran untuk mencapai prestasi yang maksimal. Pada pembelajaran kooperatif tipe Jigsaw keterlibatan guru dalam proses belajar mengajar semakin berkurang dalam arti guru tidak menjadi pusat kegiatan kelas. Guru berperan sebagai fasilitator yang mengarahkan dan memotivasi siswa untuk belajar mandiri serta menumbuhkan rasa tanggung jawab serta siswa akan merasa senang berdiskusi tentang matematika dalam kelompoknya. Mereka dapat berinteraksi dengan teman sebayanya dan juga dengan gurunya sebagai pembimbing. Dalam model pembelajaran tipe Jigsaw, meskipun guru tetap mengendalikan aturan, guru tidak lagi menjadi pusat kegiatan kelas, tetapi siswalah yang menjadi pusat kegiatan kelas. Model pembelajaran kooperatif tipe Jigsaw berbantu media flash adalah model pembelajaran kooperatif yang mendorong siswa aktif dan saling membantu dalam menguasai materi pelajaran dengan berbantu media flash untuk mencapai prestasi yang maksimal.

Pada pembelajaran kooperatif tipe Jigsaw dan Jigsaw berbantu media flash terdapat kesamaan, yaitu beberapa anggota dalam suatu kelompok menjadi pakar dan bertanggung jawab atas penguasaan tentang subbagian satu topik materi belajar serta 
mampu mengajarkan bagian tersebut kepada anggota lain dalam kelompoknya. Perbedaannya adalah untuk pembelajaran kooperatif tipe Jigsaw berbantu media flash memanfaatkan media komputer dalam pembelajaran supaya pembelajaran lebih efektif dan menarik.

Pada materi dimensi tiga tidak hanya berisi kumpulan rumus-rumus, tapi juga tentang pemahaman konsep. Siswa memerlukan kegiatan pembelajaran yang tidak hanya berpusat pada guru tetapi juga melibatkan keaktifan siswa dalam menerapkan rumusrumus tersebut ke dalam kehidupan sehari-hari. Oleh karena itu, dalam pembelajaran di kelas siswa memerlukan kegiatan diskusi agar mereka dapat bertukar pikiran dengan teman yang lain untuk memastikan bahwa tidak terdapat kesalahpamahaman dalam memahami materi dimensi tigadan siswa dapat menerapkan konsep dimensi tiga dalam menyelesaikan soal berkaitan penerapan dimensi tiga dalam kehidupan sehari-hari. Untuk dapat bertukar pikiran tentunya diperlukan keaktifan dari masing-masing siswa sehingga kegiatan diskusi dapat berjalan dengan baik. Dengan karakteristik Jigsaw yang terdiri dari dua jenis kelompok yakni kelompok asal dan kelompok ahli, dapat meningkatkan tanggung jawab individu sehingga membuat siswa tidak hanya bergantung pada teman yang pandai saat berdiskusi, akan tetapi terlibat aktif dalam menemukan penyelesaian dari persoalan yang dihadapi.

Banyak penelitian relevan yang telah dilakukan dengan model pembelajaran kooperatif tipe Jigsaw, seperti Gomleksiz (2007) mengatakan bahwa pengalaman pembelajaran kooperatif tipe Jigsaw memiliki dampak positif yang signifikan dalam mental siswa dan sekaligus menggerakkan interaksi yang lebih baik di antara siswa. Elmar dan Julia (2007) menyimpulkan bahwa metode kooperatif tipe Jigsaw memberikan hasil belajar yang lebih memuaskan (satisfactory learning results). Penelitian yang relevan dengan media pembelajaran menggunakan komputer juga telah banyak dilakukan diantaranya Sudjana dan Rivai (2001: 2-3) mengatakan bahwa media pembelajaran dapat mempertinggi proses belajar siswa dalam pembelajaran yang pada gilirannya diharapkan dapat mempertinggi hasil belajar yang dicapainya. Selain itu, penelitian yang dilakukan oleh Kusumah (2006) menyatakan bahwa pembelajaran matematika berbasiskan komputer dapat meningkatkan kemampuan pemahaman matematika dan berpikir kritis siswa.

Berdasarkan penelitian relevan di atas model pembelajaran kooperatif tipe Jigsaw dan pembelajaran menggunakan media komputer memberikan pengaruh yang positif terhadap prestasi belajar. Di dalam model pembelajaran kooperatif tipe Jigsaw terdapat faktor berdiskusi sehingga siswa dapat menggali potensi diri dan pembelajaran menjadi 
bermakna. Selain itu, dengan penggunaan media pembelajaran dengan memanfaatkan software macromedia flash diharapkan bisa lebih menarik dan interaktif sehingga dapat digunakan sebagai salah satu solusi untuk meningkatkan kualitas pembelajaran matematika khususnya pokok bahasan dimensi tiga. Oleh karena itu, peneliti tertarik untuk menerapkan model pembelajaran kooperatif tipe Jigsaw dan Jigsaw berbantu flash dalam proses pembelajaran di kelas.

Selain model pembelajaran, masih banyak hal yang mempengaruhi prestasi siswa, salah satunya adalah gaya belajar matematika siswa. Gaya belajar matematika adalah cara yang lebih disukai dalam melakukan kegiatan berpikir, memproses, dan mengerti suatu informasi. Gaya belajar matematika dikelompokkan menjadi tiga tipe yaitu visual, auditorial, dan kinestetik. Pada umumnya siswa memiliki ketiga gaya belajar tersebut, namun ada satu yang paling dominan dimilikinya. Kebanyakan siswa belum mengenal persis gaya belajar yang dimilikinya sehingga mereka belum dapat menerapkannya secara optimal. Hasil menunjukkan bahwa murid yang belajar dengan menggunakan gaya belajar mereka yang dominan saat mengerjakan tes akan mencapai nilai yang jauh lebih tinggi dibandingkan bila mereka belajar dengan cara yang tidak sejalan dengan gaya belajar mereka (Lucy, 2012:91). Gaya belajar siswa untuk menerima materi yang diberikan oleh guru berbeda-beda, selain itu setiap siswa juga memiliki karakteristik yang berbeda. Dengan perbedaan ini guru harus peka untuk dapat mengarahkan siswanya sesuai dengan kemampuan, minat dan bakat yang dimiliki oleh siswa sehingga potensi yang ada dalam diri siswa dapat dikembangkan secara optimal. Selain itu, seorang guru dalam menerapkan media pembelajaran hendaknya dapat menggunakan media dan metode yang menarik, efektif, dan interaktif.

Tujuan penelitian ini untuk mengetahui: (1) model pembelajaran yang menghasilkan prestasi belajar matematika lebih baik, model pembelajaran kooperatif tipe Jigsaw, Jigsaw berbantu media flash atau model pembelajaran langsung. (2) prestasi belajar matematika yang lebih baik, peserta didik dengan gaya belajar auditorial, visual atau kinestetik. (3) Pada masing-masing kategori gaya belajar, manakah yang memberikan prestasi belajar matematika lebih baik, antara model pembelajaran kooperatif tipe Jigsaw, Jigsaw berbantu media flash atau model pembelajaran langsung.(4) Pada masing-masing model pembelajaran, manakah yang mempunyai prestasi belajar matematika lebih baik, gaya belajar visual, auditorial, atau kinestetik. 


\section{METODOLOGI PENELITIAN}

Penelitian ini merupakan penelitian eksperimental semukarena tidak dilakukan kontrol pada semua variabel yang relevan kecuali beberapa dari variabel-variabel yang diteliti dengan desain 3x3. Populasinya adalah seluruh siswa kelas XI SMK se-Kabupaten Sragen tahun pelajaran 2015/2016. Sampling dalam penelitian dengan menggunakan teknik stratified cluster random sampling sehingga terpilih sampel berjumlah 291 siswa yang berasal dari SMK Negeri 1 Miri sebagai kelompok tinggi, SMK Muhammadiyah 1 Sragen sebagai kelompok sedang, dan SMK Negeri 1 Jenar sebagai kelompok rendah. Dari tiga sekolah tersebut, masing-masing sekolah dipilih tiga kelas secara random, satu kelas sebagai kelas eksperimen satu, satu kelas sebagai kelas eksperimen dua dan satu kelas sebagai kelas kontrol.

Metode pengumpulan data pada penelitian ini meliputi metode tes dan dokumentasi. Instrumen yang digunakan untuk mengumpulkan data adalah tes prestasi belajar matematika dan angket gaya belajar siswa. Uji instrumen tes prestasi yang digunakan adalah validitas isi, tingkat kesukaran, daya beda, dan angket gaya belajar siswa menggunakan uji validitas isi, konsistensi internal, dan reliabilitas. Data kemampuan awal dianalisis dengan menggunakan anava satu jalan dengan sel tak sama. Sebelumnya dilakukan uji prasyarat meliputi uji normalitas populasi menggunakan metode Lilliefors dan uji homogenitas menggunakan metode Bartlett. Hasil uji prasyarat disimpulkan bahwa semua sampel berasal dari populasi yang berdistribusi normal dan populasi yang dibandingkan mempunyai variansi yang sama. Hasil uji keseimbangan disimpulkan bahwa populasi mempunyai kemampuan awal yang seimbang. Uji hipotesis menggunakan analisis variansi dua jalan dengan sel tak sama. Apabila hasil analisis variansi menunjukkan bahwa hipotesis nol ditolak, dilakukan uji komparasi ganda menggunakan metode Scheffe'. (Budiyono, 2009).

\section{HASIL PENELITIAN DAN PEMBAHASAN}

Berdasarkan uji prasyarat yang telah dilakukan diperoleh kesimpulan bahwa semua sampel berasal dari populasi yang berdistribusi normal dan populasi-populasi yang mempunyai variansi sama (homogen). Hasil uji keseimbangan dengan menggunakan analisis variansi satu jalan dengan sel tak sama diperoleh kesimpulan bahwa populasi mempunyai kemampuan awal yang seimbang. Rerata prestasi belajar matematika peserta didik berdasarkan model pembelajaran dan gaya belajar siswa dapat dilihat pada Tabel 1 berikut: 
Tabel 1 Deskripsi Rataan Sel dan Rataan Marginal

\begin{tabular}{ccccc}
\hline Model & \multicolumn{3}{c}{ Tipe Gaya Belajar } & Rerata \\
\cline { 2 - 4 } Pembelajaran & Visual $\left(b_{1}\right)$ & Auditorial $\left(b_{2}\right)$ & Kinestetik $\left(b_{3}\right)$ & Marginal \\
\hline Jigsaw $\left(a_{1}\right)$ & 71,3725 & 60,6000 & 78,3077 & 71,0103 \\
\hline Jigsaw Flash $\left(a_{2}\right)$ & 77,1064 & 70,9565 & 82,3077 & 77,0417 \\
\hline Langsung $\left(a_{3}\right)$ & 66,9787 & 56,1667 & 71,1111 & 65,4694 \\
\hline Rerata Marginal & 71,8069 & 62,5672 & 77,1646 & \\
\hline
\end{tabular}

Rangkuman uji analisis variansi disajikan pada Tabel 2 berikut:

Tabel 2 Rangkuman Hasil Analisis Variansi Dua Jalan Dengan Sel Tak Sama

\begin{tabular}{ccccccc}
\hline Sumber & $\mathrm{JK}$ & $\mathrm{dk}$ & $\mathrm{RK}$ & $F_{\text {obs }}$ & $F_{\text {tabel }}$ & Keputusan \\
\hline $\mathrm{A}$ & 6311,6758 & 2 & 3155,8379 & 18,7506 & 3,00 & $H_{O A}$ ditolak \\
\hline $\mathrm{B}$ & 9542,2120 & 2 & 4771,1060 & 28,3479 & 3,00 & $H_{O B}$ ditolak \\
\hline $\begin{array}{c}\text { Interaksi } \\
\text { (AB) }\end{array}$ & 372,8759 & 4 & 93,2190 & 0,5539 & 2,407 & $H_{O A B}$ diterima \\
\hline Galat & 47462,2018 & 282 & 168,3057 & - & - & - \\
\hline Total & 63688,9655 & 290 & - & - & - & - \\
\hline
\end{tabular}

Berdasarkan Tabel 2 tersebut diperoleh hasil analisis variansi dua jalan dengan sel tak sama dengan taraf signifikan 0,05 . (1) $H_{0 \mathrm{~A}}$ ditolak sehingga terdapat perbedaan prestasi belajar matematika pada peserta didik yang diberi perlakuan model pembelajaran kooperatif tipe Jigsaw, Jigsaw berbantu media flash dan pembelajaran langsung. (2) $H_{0 \mathrm{~B}}$ ditolak sehingga terdapat perbedaan prestasi belajar matematika antara peserta didik dengan gaya belajar visual, auditorial, atau kinestetik.(3) $H_{0 \mathrm{AB}}$ diterima sehingga tidak terdapat interaksi antar model pembelajaran dan gaya belajar siswa terhadap prestasi belajar matematika. Hasil uji komparasi rerata antar baris dapat disajikan pada Tabel 3 berikut:

Tabel 3Rangkuman Uji Komparasi Rerata Antar Baris

\begin{tabular}{cccc}
\hline $\mathrm{H}_{0}$ & $\mathrm{~F}_{\text {obs }}$ & $2 \mathrm{~F}_{0,05 ; 2 ; 282}$ & Keputusan Uji \\
\hline$\mu_{1 .}=\mu_{2 .}$ & 10,4284 & 6,00 & $\mathrm{H}_{0}$ ditolak \\
\hline$\mu_{2 .}=\mu_{3 .}$ & 38,5864 & 6,00 & $\mathrm{H}_{0}$ ditolak \\
\hline$\mu_{1 .}=\mu_{3 .}$ & 8,8926 & 6,00 & $\mathrm{H}_{0}$ ditolak \\
\hline
\end{tabular}

Berdasarkan Tabel 3 diketahui terdapat perbedaan prestasi belajar matematika antara siswa yang diberi model pembelajaran kooperatif tipe Jigsaw dengan model pembelajaran kooperatif tipe Jigsaw flash maupun dengan pembelajaran langsung. Dengan memperhatikan rerata marginal pada Tabel 1 diperoleh kesimpulan sebagai berikut. (1) Prestasi belajar matematika siswa dengan model pembelajaran kooperatif tipe Jigsaw berbantu media flash lebih baik daripada model pembelajaran kooperatif tipe Jigsaw. (2) Prestasi belajar matematika siswa dengan model pembelajaran kooperatif tipe Jigsaw berbantu media flash lebih baik daripada model pembelajaran langsung. (3) Prestasi belajar matematikaJigsawdengan model pembelajaran kooperatif tipe 
Jigsawlebih baik daripada model pembelajaran langsung. Hasil penelitian ini sesuai dengan penelitian yang dilakukan Elmar dan Julia (2007), yaitu prestasi belajar matematika peserta didik dengan model pembelajaran kooperatif tipe Jigsaw lebih baik daripada model pembelajaran langsung. Hasil penelitian tersebut juga sejalan dengan penelitian Gomleksiz (2007) yang menyatakan bahwa pengalaman pembelajaran kooperatif (Jigsaw) memiliki dampak positif yang signifikan. Model pembelajaran kooperatif tipe Jigsaw berbantu media flash menghasilkan prestasi belajar matematika lebih baik daripada model pembelajaran langsung, hal tersebut sesuai dengan hasil penelitian Risma Jayanti (2007) yang menyimpulkan bahwa pembelajaran matematika dengan Macromedia Flash sebagai alat untuk meningkatkan motivasi dan minat belajar siswa sehingga prestasi belajar matematika dapat ditingkatkan.

Berdasarkan Tabel 2 diketahui $\mathrm{H}_{0 B}$ ditolak sehingga untuk mengetahui model pembelajaran mana yang menghasilkan prestasi berbeda maka perlu dilakukan uji komparasi ganda antar kolom. Rangkuman uji komparasi ganda antar kolom ditunjukkan oleh Tabel 4 berikut.

Tabel 4 Rangkuman Uji Komparasi Ganda Antar Kolom

\begin{tabular}{cccc}
\hline $\mathrm{H}_{0}$ & $\mathrm{~F}_{\text {obs }}$ & $2 \mathrm{~F}_{0,05 ; 2 ; 282}$ & Keputusan Uji \\
\hline$\mu_{1 .}=\mu_{2 .}$ & 23,2449 & 6,00 & $\mathrm{H}_{0}$ ditolak \\
\hline$\mu_{2 .}=\mu_{3 .}$ & 45,8987 & 6,00 & $\mathrm{H}_{0}$ ditolak \\
\hline$\mu_{1 .}=\mu_{3 .}$ & 8,7217 & 6,00 & $\mathrm{H}_{0}$ ditolak \\
\hline
\end{tabular}

Berdasarkan Tabel 4 tersebut diperoleh kesimpulan sebagai berikut: (1) Hipotesis pertama, keputusan $\mathrm{uji} H_{0}$ ditolak, hal ini berarti bahwa ada perbedaan prestasi belajar matematika antar siswa. Berdasarkan rerata marginalnya prestasi belajar matematika siswa dengan gaya belajar visual lebih baik daripada gaya belajar auditorial. (2) Hipotesis kedua, keputusan uji $H_{0}$ ditolak, hal ini berarti bahwa ada perbedaan prestasi belajar matematika antar siswa. Berdasarkan rerata marginalnya prestasi belajar matematika siswa dengan gaya belajar kinestetik lebih baik daripada gaya belajar auditorial. (3) Hipotesis ketiga, keputusan uji, $H_{0}$ ditolak, hal ini berarti bahwa ada perbedaan prestasi belajar matematika antar siswa. Berdasarkan rerata marginalnya prestasi belajar matematika siswa dengan gaya belajar kinestetik lebih baik daripada gaya belajar visual. Hasil penelitian ini sejalan dengan penelitian yang dilakukan oleh Ayuning Tyas Wulandari (2007) yang menyatakan ada pengaruh gaya belajar terhadap prestasi belajar. Serta penelitian yang dilakukan oleh Zamroni (2013) yang menyatakan bahwa prestasi belajar matematika siswa dengan gaya belajar kinestetik lebih baik daripada gaya belajar visual dan auditorial. 
Berdasarkan Tabel 2 diketahui $\mathrm{H}_{O A B}$ diterima sehingga tidak terdapat interaksi antara model pembelajaran dan gaya belajar siswa terhadap prestasi belajar matematika siswa. Hal ini berarti bahwa gaya belajar visual, auditorial dan kinestetik untuk setiap model pembelajaran sama. Dengan demikian tidak perlu dilakukan uji komparasi antarsel, karena karakteristik tersebut sama dengan karakteristik gaya belajar siswa dan karakteristik model pembelajaran.

Tidak adanya interaksi antara model pembelajaran dan gaya belajar siswa terhadap prestasi belajar matematika siswa disebabkan adanya variabel bebas lain yang berpengaruh karena keterbatasan penelitian tidak terkontrol dalam penelitian ini. Oleh karena itu untuk mengetahui keefektifan model pembelajaran pada masing-masing gaya belajar siswa mengacu pada kesimpulan perbandingan rerata marginalnya. Sehingga bisa disimpulkan bahwa: pada masing-masing gaya belajar siswa, prestasi belajar siswa yang diberi model pembelajaran Jigsaw Flash lebih baik daripada model pembelajaran Jigsaw maupun langsung dan prestasi belajar siswa yang diberi model pembelajaran Jigsaw lebih baik daripada model pembelajaran langsung.

\section{SIMPULAN DAN SARAN}

Berdasarkan hasil analisis simpulan dari penelitian ini sebagai berikut. (1) Model pembelajaran kooperatif tipe Jigsaw Flash menghasilkan prestasi belajar matematika lebih baik daripada model pembelajaran kooperatif tipe Jigsaw dan langsung pada materi dimensi tiga, model pembelajaran kooperatif tipe Jigsaw menghasilkan prestasi belajar matematika lebih baik daripada model pembelajaran langsung pada materi materi dimensi tiga. (2) Prestasi belajar matematika siswa yang mempunyai gaya belajar tipe kinestetik lebih baik daripada prestasi belajar matematika siswa yang mempunyai gaya belajar tipe visual dan tipe auditorial, dan prestasi belajar matematika siswa yang mempunyai gaya belajar tipe visual lebih baik daripada prestasi belajar matematika siswa yang mempunyai gaya belajar tipe auditorial. (3) Pada masing-masing gaya belajar visual, auditorial dan kinestetik, model pembelajaran kooperatif tipe Jigsaw Flash memberikan prestasi belajar matematika lebih baik daripada model pembelajaran kooperatif tipe Jigsaw maupun pembelajaran langsung. Model pembelajaran kooperatif tipe Jigsaw memberikan prestasi belajar matematika lebih baik daripada model pembelajaran langsung. (4) Pada masingmasing model pembelajaran yaitu model pembelajaran Jigsaw Flash, Jigsaw, dan pembelajaran langsung, siswa yang memiliki gaya belajar kinestetik mempunyai prestasi belajar matematika lebih baik daripada siswa yang memiliki gaya belajar visual maupun 
auditorial, dan siswa yang memiliki gaya belajar visual mempunyai prestasi belajar matematika lebih baik daripada siswa yang memiliki gaya belajar auditorial.

Saran terkait hasil penelitian tersebut adalah guru hendaknya selalu memperluas wawasannya mengenai model pembelajaran, seperti model pembelajaran Jigsaw dan Jigsaw berbantu media flash untuk diterapkan dalam penerapan proses pembelajaran. Guru sebaiknya juga memperhatikan gaya belajar yang dimiliki siswa agar proses pembelajaran dapat berlangsung dengan baik dan menghasilkan prestasi belajar yang maksimal.Bagi peneliti lain, diharapkan dapat meneruskan atau mengembangkan penelitian ini dengan variabel/model lain yang lebih inovatif sehingga dapat meningkatkan kualitas pembelajaran khususnya dan pendidikan pada umumnya.

\section{DAFTAR PUSTAKA}

Ayuning, T. 2007 "Eksperimentasi Metode Pembelajaran Contextual Teaching Learning (CTL) pada pokok Bahasan Peluang Ditinjau Dari Gaya Belajar Matematika Siswa Kelas IX SMP Negeri I Donorojo Tahun Pelajaran 2006/2007”. Tesis: UNS, Surakarta.

Attle, S \& Baker, B. 2007. Cooperative Learning in a Competitive Environment : Classroom Applications. International Journal of Teaching and Learning in Higher Education. Volume 19, Number 1, 77-83 ISSN 1812-9192.

Budiyono. 2009. Statistika Untuk Penelitian. Surakarta: UNS Press.

Elmar, S., Julia, K. 2007. Cooperative learning in third graders' Jigsaw groups for mathematics and science with and without questioning training. British Journal of Educational Psychology, 77 (4): 755-771, http://www.eric.ed.gov/, diakses tanggal 6 Februari 2013.

Gomleksiz, M.N. 2007. "Effectiveness of cooperative learning (Jigsaw II) method in teaching English as a foreign language to engineering students (case of Firat University, Turkey). European journal of engineering education.32(5):613-625, http://eric.ed.gov/, diakses tanggal 10 Februari 2013.

Kusumah, Yaya S. 2006. Studi Tentang Penerapan Model Pembelajaran Matematika Berbasis Komputer Tipe Interaksi Tutorial dalam Peningkatan Kemampuan Berpikir Kritis dan Kreatif Siswa (Makalah) dalam Prosiding Konferensi Matematika XIII. Semarang: Jurusan Matematika FMIPA Unnes bekerjasama dengan Badan Penerbit Universitas Diponegoro.

Lucy dan Ade.J. 2012. Dahsyatnya Brain Smart Teaching. Jakarta: Penebar Plus.

Parveen, Q \& Batool, S. 2012. Effect of Cooperative Learning on Achievement of Student in General Science at Secondary Level. International Education Studies. Vol.5 No.2 ISSN 1913-9020. 
Price, A.T.1999. analysing data on the relationship between teacing and learning addition in a primary classroom. International Journal of The British Society for Research into Learning Mathematies 19(2) June 1999.

Risma, J.2007" Perancangan Media Pembelajaran Berbasis Teknologi Informasi dan Komunikasi (TIK) di Sekolah Menengah Atas pada Pokok Bahasan Logaritma (Kelas X Semester 1 SMA Negeri 2 Sukoharjo)".Skripsi:UMS, Surakarta.

Slavin, R.E. 2010. Cooperative Learning Teori, Riset, dan Praktik. Terjemahan Narulita Yusron. Bandung: Nusa Media.

Slameto. 2010. Belajar dan Faktor-faktor yang Mempengaruhinya. Jakarta: Rineka Cipta.

Sudjana, Nana. 2009. Penilaian hasil proses belajar mengajar. Bandung: PT Remaja Rosdakaya.

TIMSS. 2011.(http://nces.ed.gov/Timss//results99_1.asp). Di unduh pada tanggal 15 September 2015.

Undang - undang Sistem Pendidikan Nasional No.20 Tahun 2003.2003. Jakarta: Sisdiknas.

Wilantara .I Putu Eka (2003).Implementasi Model Belajar Konstruktivis dalam Pembelajaran Fisika untuk Mengubah Miskonsepsi Ditinjau dari Penalaran Formal Siswa. Tesis: IKIP Singaraja Bali.[Online]. www.damandiri.or.id/file/iputuekaikipsingbab1.pdf. di akses pada tanggal 15 September 2015.

Zamroni. 2013"Eksperimentasi Pembelajaran Kooperatif Tipe STAD dan TPS dengan Pendekatan CTL pada Materi Pokok Sistem Persamaan Linear Dua Variabel ditinjau dari Gaya Belajar Siswa". UNS, Surakarta. 